\title{
PENGARUH INTELLECTUAL CAPITAL DAN PENGUNGKAPAN CORPORATE SOCIAL RESPONSIBILITY TERHADAP RETURN SAHAM
}

\author{
Amelia Septiana, Sukamto, Wiwin Wahyuni \\ Fakultas Ekonomi dan Bisnis, Universitas Wijaya Kusuma Surabaya \\ e-mail: ameliaseptiana@gmail.com
}

\begin{abstract}
This research aimed to look at the impact of Intellectual Capital and Corporate Social Responsibility Disclosure on the stock returns of manufacturing companies. Intellectual Capital, as measured by the Public-VAIC (Value Added Intellectual Coefficient) model of the company's three key resources (human capital, structural capital, and customer capital), and Corporate Social Responsibility Transparency, as measured by the CSRDI, were the independent variables in this analysis. Stock Return is the dependent variable. An empirical study is what this form of research is. Purposive sampling is used to pick the samples. In this analysis, 80 manufacturing companies that were listed on the Indonesia Stock Exchange (IDX) in 2018 were used as a sample. The findings revealed that Intellectual Capital had a substantial impact on stock returns, while Corporate Social Responsibility Disclosure had no impact.
\end{abstract}

Keywords: $\quad$ intellectual capital; corporate social responsibility; VAIC; CSRDI; stock return

\begin{abstract}
ABSTRAK
Penelitian ini bertujuan untuk menganalisa pengaruh Intellectual Capital dan Pengungkapan Corporate Social Responsibility terhadap Return Saham di Perusahaan Manufaktur. Variabel Independen yang digunakan pada penelitian ini yaitu Intellectual Capital yang diukur menggunakan model Pulic-VAIC (Value Added Intellectual Coefficient) dari tiga sumber daya utama perusahaan (human capital, structural capital dan customer capital), serta pengungkapan Corporate Social Responsibility yang diukur menggunakan CSRDI. Variabel Dependen yang digunakan pada penelitian adalah Return Saham. Jenis penelitian ini merupakan studi empiris, sedangkan pemilihan sampelnya menggunakan metode purposive sampling. Sampel dalam penelitian ini sebanyak 80 Perusahaan Manufaktur yang terdaftar di Bursa Efek Indonesia (BEI) Tahun 2018. Hasil penelitian menunjukkan bahwa Intellectual Capital berpengaruh signifikan terhadap Return Saham, dan Pengungkapan Corporate Social Responsibility tidak berpengaruh terhadap Return Saham.
\end{abstract}

Kata Kunci: intellectual capital; corporate social responsibility; VAIC; CSRDI; return saham

\section{PENDAHULUAN}

Penilaian dan pengukuran dapat dilakukan dalam meningkatkan kinerja suatu perusahaan, bukan hanya pada aset berwujud (tangible asset), akan tetapi juga pada aset tak berwujud (intangible asset). Salah satu pendekatan yang dipakai dalam penghitungan dan pengukuran aset tidak berwujud yaitu modal intelektual yang telah menjadi fokus dalam berbagai macam bidang, baik di manajemen ataupun akuntansi. (Caroline 2015). Aset tidak berwujud untuk memperlihatkan tuntutan hukum pada masa depan. Intellectual Capital adalah nilai yang dipunyainya tidak berhubungan dengan wujud fisiknya, atau aset tidak berwujud. Intellectual Capital adalah asset yang tidak berwujud pada sumber daya informasi dan pengetahuan yang berperan dalam menaikkan kemampuan bersaing dan bisa menaikkan kinerja perusahaan (Bontis, 2000). Intellectual capital atau modal intelektual mempunyai peranan utama dalam menaikkan nilai perusahaan.

Dalam perusahaan terdapat beberapa faktor yang dapat meningkatkan return saham diantaranya adalah Intellectual Capital dan Corporate Social Responsibility. Peningkatan, pengenalan, dan pemanfaatan Intellectual Capital pada suatu perusahaan, akan menunjang meningkatkan kinerja keuangan perusahaan tersebut sehingga kepercayaan stakeholder pada going concern ikut meningkat sehingga akan mempengaruhi return saham perusahaan (Abidin, 2003). 
p-ISSN 1693-1378

e-ISSN 2598-9952

Meningkatkan akitivitas lingkungan dan kegiatan sosial adalah bentuk tanggung jawab atau kepedulian perusahaan pada lingkungan sekitarnya juga akan membantu perusahaan meningkatkan kinerja keuangan sehingga jika kinerja perusahaan baik, maka akan semakin tinggi keinginan investor untuk berinvestasi di perusahaan tersebut, dengan kinerja yang baik diharapkan return yang semakin besar (Agusta dan Agustinus, 2017). Pemilihan perusahaan manufaktur dikarenakan asumsi jika perusahaan manufaktur pada sektor tersebut yang selama ini sering dihubungkan dengan alat-alat dan mesin pabrik yang hanya membutuhkan sedikit sentuhan sumber daya manusia di dalamnya, padahal dalam keberhasilan suatu perusahaan tidak hanya dikarenakan tangible assets yang mereka punyai tetapi juga intangible assets yang berada di belakangnya (Caroline, 2015). Selain itu perusahaan manufaktur merupakan perusahaan yang banyak menimbulkan efek lingkungan pada daerah sekitarnya dalam proses produksi seperti limbahlimbah yang tidak didaur sehingga perusahaan perlu menerapkan program Corporate Social Responsibility sebagai timbal balik kepada lingkungan sekitarnya (Deegan, 2002). Penelitian ini bertujuan yaitu untuk membuktikan studi empiris mengenai Intellectual Capital dan pengungkapan Corporate Social Responsibility terhadap Return saham pada perusahaan manufaktur yang terdaftar di Bursa Efek Indonesia tahun 2018.

\section{METODE PENELITIAN}

Penelitian ini memakai pendekatan kuantitatif, riset yang ditekankan pengujiian hipotesis (Ghozali, 2013). Dimana data dipakai dalam penelitian harus terukur dan mendapatan simpulan yang digeneralisasi dengan menggunakan metode atau analisis statistik untuk melakukan pengujiannya. Penelitian berguna untuk membuktikan berapa besar variabel independen mempengaruhi variabel dependent.

Populasi adalah sekelompok orang, kejadian ataupun segala sesuatu yang memiliki karakteristik tertentu (Ghozali, 2013). Populasi yang digunakan dalam penelitian ini yaitu laporan keuangan tahunan (annual report) dari perusahaan-perusahaan manufaktur yang terdaftar di Bursa Efek Indonesia (BEI). Alasan penelitian ini menggunakan populasi perusahaan manufaktur karena yang terdaftar di Bursa Efek Indonesia dikarenakan perusahaan manufaktur yang ada di Indonesia untuk memegang peranan penting terhadap pertumbungan ekonomi nasiona, karena laporan keuangan tahunan (annual report) merupakan salah satu sumber informasi keuangan yang diberikan perusahaan kepada publik
Pengaruh Intellectual Capital... (Amelia Septiana, Sukamto, Wiwin Wahyuni)

terutama para investor. Periode pengamatan dalam penelitian ini adalah tahun 2018. Jumlah populasi sebanyak 154.

Variabel dalam penelitian ini terdiri dari variabel independen adalah Intellectual Capital (X1) dan Pengungkapan Corporate Social Responsibility (X2) sedangkan variabel dependen dalam penelitian ini adalah return saham.

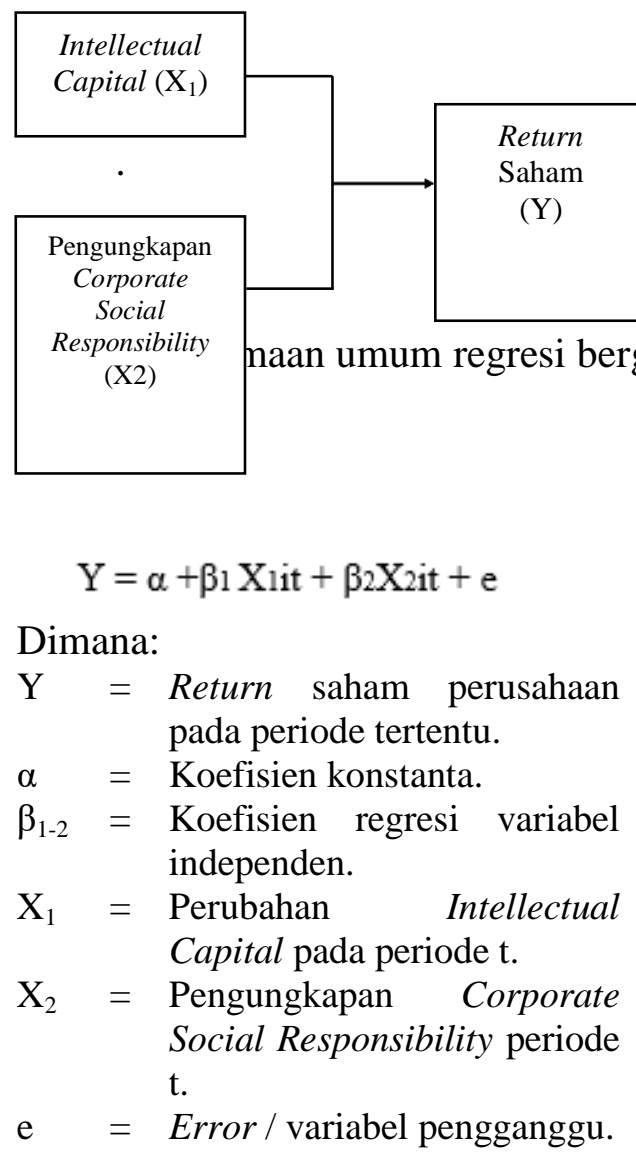

\section{PEMBAHASAN}

Penelitian ini menunjukkan hasil dari data yang diamati dan dianalisis untuk mengetahui Intellectual Capital dan Corporate Social Responsibility terhadap return saham sebagai variabel terikat di perusahaan manufaktur yang terdaftar di Bursa Efek Indonesia (BEI) tahun 2018.

Diketahui bahwa pada variabel Intellectual Capital $\left(\mathrm{X}_{1}\right)$ yang berjumlah 80 data, nilai minimumnya adalah 2,240 pada PT. Primarindo Asia Infrastructure Tbk, nilai maksimumnya 56,670, pada PT. Buyung Poetra Sembada Tbk, rata-rata 15,61625 dan standar deviasi 10,34. Berdasarkan hasil analisis statistik deskriptif menunjukan bahwa nilai rata-rata Intellectual Capital adalah 15,61 dengan standart deviasi 10,34. Dengan demikian dapat dapat dilihat bahwa nilai standar deviasi lebih kecil dari pada nilai rata - rata. Hal ini menunjukan bahwa variabel Intellectual Capital yang di gunakan 
oleh penelitian ini tidak bervariasi. Pada variabel Corporate Social Responsibility $\left(\mathrm{X}_{2}\right)$ yang berjumlah 80 data, nilai minimumnya adalah 0,077 pada PT. Trisula Textile Industries Tbk, PT. Fajar Surya Wisesa Tbk, PT. Kimia Farma (Persero) Tbk nilai maksimumnya 0,297 pada PT. Unilever Indonesia Tbk rata-rata 0,160 dan standar deviasi 0,487 Nilai rata rata 0,160 menunjukkan bahwa perusahaan dalam menerapkan pengunkapan Corporate Social Responsibility sebesar 0,160. Nilai rata rata 0,160 lebih kecil dari standart deviasi 0,487 hal ini mengidikasi bahwa peyebaran data untuk Corporate Social Responsibility adalah merata tidak terdapat data perbedaan data yang tinggi antara data yang satu dengan yang lainnya. Pada variabel Return Saham (Y) yang berjumlah 80 data, nilai minimumnya adalah $-0,708$ pada PT. Campina Ice Cream Industry Tbk, nilai maksimumnya 1,571 pada PT. Indomobil Sukses International Tbk, rata-rata 0,142 dan standar deviasi 0,461. Artinya setiap lembar saham menghasilkan tingkat keuntungan sebesar Rp 0,142. Nilai rata-rata sebesar 0,142 lebih kecil dari standar deviasi 0,461 menunjukkan bahwa data Return Saham penyebarannya tidak merata artinya terdapat perbedaan data yang tinggi antara yang satu dengan yang lainnya.

\section{Tabel 1}

Hasil Uji Statistik Diskriptif

\begin{tabular}{lcccrc}
\hline & $\mathrm{N}$ & Min & Max & Mean & $\begin{array}{l}\text { Std. } \\
\text { Dev }\end{array}$ \\
\hline IC & 80 & 2,24 & 56,67 & 15,61 & 10,34 \\
\hline CSR & 80 & 0,077 & 0,297 & 0,16 & 0,048 \\
\hline $\begin{array}{l}\text { Return } \\
\text { saham }\end{array}$ & 80 & $-0,708$ & 1,571 & 0,142 & 0,461 \\
\hline $\begin{array}{l}\text { Valid N } \\
\text { (listwise) }\end{array}$ & 80 & & & & \\
\hline Sumber: & Hasil pengolahan data SPSS versi 20.0
\end{tabular}

Nilai signifikansi adalah 0,031. Karena nilai signifikansi $0,031<0,05$ maka $\mathrm{H} 0$ ditolak dan H1 diterima. Hal ini menunjukkan bahwa Intellectual Capital $\left(\mathrm{X}_{1}\right)$ dan Corporate Social Responsibility $\left(\mathrm{X}_{2}\right)$ secara serentak atau bersama sama berpengaruh terhadap Return saham (Y). Berdasarkan hasil persamaan regresi berganda uji $\mathrm{F}$ menunjukkan nilai hitung $F$ sebesar 3,652 dengan nilai signifikansi $0,031<0,05$ bermakna hipotesis dapat diterima.

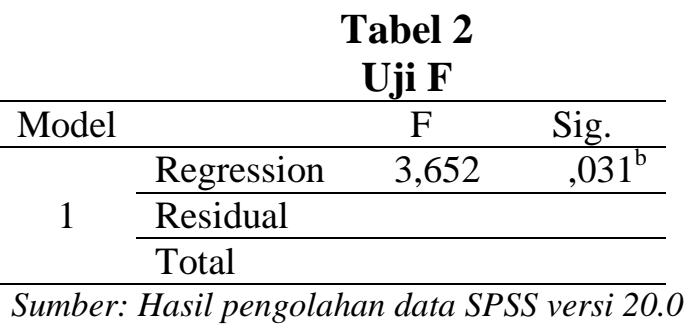

Variabel Intellectual Capital mempunyai nilai signifikansi sebesar 0,010. Signifikansi $0,010<0,05$ maka H0 ditolak dan $\mathrm{H} 1$ diterima. Hal ini menunjukkan bahwa variabel Intellectual Capital $\left(\mathrm{X}_{1}\right)$ berpengaruh signifikan terhadap Return saham (Y). nilai signifikansi $0,421>0,05$ maka $\mathrm{H} 0$ diterima dan $\mathrm{H} 1$ ditolak. Hal ini menunjukkan bahwa variabel Corporate Social Responsibility $\left(\mathrm{X}_{2}\right)$ tidak berpengaruh signifikan terhadap Return saham (Y).

Tabel 3

Uji t

\begin{tabular}{|c|c|c|c|}
\hline Model & & $\mathrm{T}$ & Sig. \\
\hline \multirow{3}{*}{1} & (Constant) & 0,406 & 0,686 \\
\hline & IC & 2,657 & 0,01 \\
\hline & CSR & $-0,808$ & 0,421 \\
\hline
\end{tabular}

Berdasarkan hasil uji t, dapat disimpulkan bahwa Ho ditolak dan Ha diterima, hal ini berarti Intellectual Capital $\left(\mathrm{X}_{1}\right)$ berpengaruh terhadap Return Saham. Hasil penelitian ini menunjukan besar kecilnya Intellectual Capital mempengaruhi peningkatan Return saham. Apabila suatu perusahaan memiliki human capital yang baik seperti kemampuan, keahlian, ketrampilan, pengetahuan, dan performa bisnis yang dimiliki oleh karyawan serta memiliki structural capital (struktur internal organisasi) yang terorganisir sesuai dengan kebutuhan perusahaan sehingga tidak ada bagian divisi yang berfungsi tidak sebagaimana mestinya dan juga memiliki physical capital atau kemampuan perusahaan mengelola dana yang tersedia dengan baik. Bila ketiga komponen dari Intellectual Capital tersebut bagus maka investor akan tertarik untuk menanamkan modalnya, sehingga permintaan saham akan bertambah yang dapat mengakibatkan harga saham naik dan meningkatkan return saham perusahaan.

Intellectual Capital digunakan untuk semua yang merupakan asset dan sumberdaya non-tangible atau non-physical dari sebuah organisasi, yaitu mencakup proses, kapasitas inovasi, pola-pola, dan pengetahuan yang tidak kelihatan dari para anggotanya dan jaringan kolaborasi serta hubungan organisasi. Intellectual capital juga didefinisikan sebagai kombinasi dari sumber daya-sumber daya intangible dan kegiatan-kegiatan yang membolehkan organisasi mentransformasi sebuah kumpulan material, keuangan dan sumberdaya manusia dalam sebuah kecakapan sistem untuk menciptakan stakeholder value (Bontis, 2000). 
p-ISSN 1693-1378

e-ISSN 2598-9952

\section{PENUTUP}

\section{Simpulan, Saran dan Keterbatasan}

Simpulan

1. Berdasarkan Uji F Intellectual Capital $\left(\mathrm{X}_{1}\right)$ dan Pengungkapan Corporate Social Responsibility $\left(\mathrm{X}_{2}\right)$ berpengaruh terhadap Return saham (Y) perusahaan manufakur. Hal ini berarti bahwa model penelitian ini adalah fit atau dengan kata lain model penelitian ini layak digunakan.

2. Berdasarkan Uji t variabel Intellectual Capital $\left(\mathrm{X}_{1}\right)$ berpengaruh signifikan terhadap Return saham (Y) perusahaan manufakur. Hal ini berarti bahwa semakin tingginya Intellectual Capital yang dimiliki perusahaan maka semakin tinggi juga Return saham yang diterima oleh investor yang menanam modal pada perusahaan tersebut.

3. Hasil uji signifikansi pada opini auditor menunjukkan nilai signifikansi besarnya 0,011 $(0,011<0,05)$. Angka tersebut menyatakan opini auditor berpengaruh terhadap ketepatan waktu penyampaian laporan keuangan.

Saran

1. Bagi para investor, untuk melakukan analisis Intellectual Capital sebelum investasi dalam suatu perusahaan.

2. Bagi perusahaan, hasil riset ini dapat memberi informasi terhadap manajemen perusahaan bahwa dalam kinerja suatu perusahaan dilakukan penilaian dan pengukuran tidak cukup pada asset berwujud tetapi juga pada asset tidak berwujud yaitu Intellectual Capital.

3. Bagi riset selanjutnya, sebaiknya peneliti tidak sekedar mengambil sampel satu bidang saja dan sebaiknya periode tahun pengamatan ditambah sehingga dapat dianalisis apakah tahun-tahun sebelumnya variable Intellectual Capital dan Pengungkapan Corporate Social Responsibility berpengaruh terhadap Return saham karena setiap tahun bisa saja berbeda yang disebabkan oleh faktor lain seperti tingkat suku bunga, tingkat inflasi dan kondisi politik.

Keterbatasan

1. Penelitian hanya menggunakan 1 tahun dengan sampel penelitian yang terbatas, yakni sebesar 80 sampel penelitian.
Pengaruh Intellectual Capital... (Amelia Septiana, Sukamto, Wiwin Wahyuni)

2. Perusahaan yang dijadikan sampel juga terbatas pada industri manufaktur sehingga kurang mewakili dari seluruh sektor industri yang terdaftar di BEI.

3. Penggunaan variabel yang mempengaruhi Return saham perusahaan. hanya menggunakan variabel Intellectual Capital dan Pengungkapan Corporate Social Responsibility. Masih banyak variabel lain yang berpengaruh dan tidak disertakan dalam penelitian ini.

\section{DAFTAR PUSTAKA}

Abidin, Sawarjuwono dan Kadir. (2003). Intellectual Capital Disclosure Commitment : Myth or Reality, Journal of Intellectual Capital, Vol.13, No. 1, pp. 39-56

Agusta, Alwin dan Agustinus S A. (2017). Analisis Pengaruh Modal Intelektual terhadap Profitabilitas, Produktifitas, dan Penilaian Pasar Perusahaan (Studi Kasus pada 35 Perusahaan LQ45 di Bursa Efek Indonesia Periode 2012-2014). Diponegoro Journal of Accounting. Vol. 6 No. 2

Bontis, N., Keow, W.C.C \& Richardson, S. (2000). Intelectual Capital and bussines performance in Malaysian industries. Joernal of Intelectual capital, 1(1), page 85-100.

Caroline, Annauly Maria. (2015). Pengaruh Modal Intelektual Terhadap Profitabilitas Perusahaan. Studi Empiris pada Perusahaan Manufaktur yang Terdaftar di Bursa Efek Indonesia Tahun 2011-2013. Skripsi, Universitas Diponegoro, Semarang.

Deegan, C., Rankin, M. Tobin, J. (2002). An examination of the corporate social and environmental disclosure of BHP from 19831997: A test of legitimacy theory. Accounting, Auditing \& Accountability Journal, Vol. 15 ISS: 3 , pp.312-343

Ghozali, I. (2013). Aplikasi Analisis Multivariate Dengan Program IBM SPSS 20 Update PLS Regresi. Semarang: Badan Penerbit Universitas Diponegoro. 